\title{
SELECTION OF STRAIS PRODUCING FUNGAL CHITOSANASE AND KINETICS
}

\author{
R. C. SILVA FILHO, S. C. SANTANA, N. KHAN, E. S. SANTOS e G. R. MARCEDO \\ Universidade Federal do Rio Grande do Norte - Depto. de Engenharia Química \\ Caixa Postal 476 - 59.021-900 Natal - RN \\ junrai@eq.ufrn.br
}

Artigo submetido em maio/2011 e aceito em junho/2011

\begin{abstract}
In this work it was performed a selection of fungal strains able to grow in a specific medium containing chitosan (Chitosan Detector Agar) as the sole carbon source at $0.2 \%$, and a kinetic study was performed to evaluate the best conditions for production of chitosanase from the best producing strain. The selection was made from five strains, previously isolated from soil. In the evaluation of kinetics was accompanied by cell concentration, the protein
\end{abstract}

concentration $(\mathrm{mg} / \mathrm{mL})$, the enzyme activity $(\mathrm{U} / \mathrm{mL})$ for two volumes of fermentation broth $(0.05$ and $0.10 \mathrm{~mL})$. The results showed a significant increase in all parameters studied in the first 12 hours of culture. Comparing the activity values for the two volumes of fermentation broth was observed that the volume of $0.05 \mathrm{~mL}$ broth showed enzymatic activity always greater than the volume of $0.1 \mathrm{~mL}$.

KEY-WORDS: chitosan; chitosanase; kinetics; Aspergillusochraceus.

\section{SELEÇÃO DE CEPAS FÚNGICAS PRODUTORAS DE QUITOSANASE E CINÉTICA}

\section{RESUMO}

No presente trabalho foi realizada uma seleção de cepas fúngicas capazes de crescer em meio específico contendo quitosana (Chitosan Detector Agar) como única fonte de carbono na concentração de $0,2 \%$, bem como foi efetuado um estudo cinético para se avaliar as melhores condições para produção da quitosanase a partir da melhor cepa produtora. Para a seleção partiu-se de cinco cepas, isoladas previamente do solo. $\mathrm{Na}$ avaliação da cinética acompanhou-se a concentração celular $(X)$, a concentração de proteínas $(\mathrm{mg} / \mathrm{mL})$, a atividade enzimática $(\mathrm{U} / \mathrm{mL})$ para dois volumes de caldo fermentativo $(0,05$ e $0,10 \mathrm{~mL})$. Os resultados mostraram que houve um aumento significativo em todos os parâmetros estudados nas primeiras 12 horas de cultivo. Comparando-se os valores de atividade para os dois volumes de caldo fermentativo foi observado que o volume de $0,05 \mathrm{~mL}$ de caldo enzimático apresentou atividade sempre maior que o volume de $0,1 \mathrm{~mL}$.

PALAVRAS-CHAVE: quitosana; quitosanase; cinética; Aspergillus ochraceus. 


\section{SELECTION OF STRAIS PRODUCING FUNGAL CHITOSANASE AND KINETICS}

\section{INTRODUCTION}

Chitin is an abundant polysaccharide in nature (GOODAY, 1990) and constitutes $1.4 \%$ of the weight of insects and $15 \%$ to $20 \%$ by weight of the shells of crustaceans. Given its potentialweight in the shells of crayfish and because of the large growth of the shrimp industry $(A B C C)$, the solid waste industry that represent a potential source of raw material for obtaining products with higher added value (POLIMAR, 2003), such as chitosanandquitooligossacarídeos. The conversion of chitosan to oligosaccharides can occur by chemical or enzyme, and the chemical pathway causes a major environmental impact since they use concentrated acids (SILVA FILHO, 2005). In this case, the hydrolysis becomes more attractive since it does not pollute the environment and be more specific.

The production of enzymes, as well as its use has been showing great acceptance in industrial processes since they are composed of natural, biodegradable and carrying out specific reactions, i.e. without producing byproducts.

Thus, this paper aims to contribute to the development of a kinetic study to determine the best conditions for producing the enzyme chitosanase produced by the fungus. To this will be monitored for 108 hours the following parameters: cell concentration $(X)$ in terms of dry mass $\left(\mathrm{g} \cdot \mathrm{L}^{-1}\right)$, total protein concentration $\left(\mathrm{mg} \cdot \mathrm{mL}^{-1}\right)$ and chitosanolytic activity $\left(\mathrm{U} \cdot \mathrm{mL}^{-1}\right)$.

\section{MATERIAL AND METHODS}

\section{1- Methods of Analysis and Preparation of Inoculum}

Selection of strain: It was used in this work a fungus chosen among five strains, isolated from soil and available in the Laboratory of Biochemical Engineering (LEB), Department of Chemical Engineering (DEQ), Federal University of Rio Grande do Norte. This strain was chosen for being able to grow on medium containing chitosan as the sole carbon and energy source.

Maintenance: The maintenance medium was the medium of cells CZAPEK AGAR, whose composition for $1000 \mathrm{~mL}$ is as follows: $30.0 \mathrm{~g}$ sucrose, $3.0 \mathrm{~g} \mathrm{NaNO}, 1.0 \mathrm{~g}$ K2HPO4, $0.5 \mathrm{~g}$ $\mathrm{KCl}, 0.5 \mathrm{~g} \mathrm{MgSO} 4.7 \mathrm{H} 2 \mathrm{O}, 0.01 \mathrm{~g}$ FeSO4.7H2O, $15.0 \mathrm{~g}$ Agar.

Inoculum: The culture medium for inoculum preparation for an $1000 \mathrm{~mL}$ was as follows: 30.0 g sucrose, $3.0 \mathrm{~g}$ NaNO3, $1.0 \mathrm{~g} \mathrm{K2HPO4,} 0.5 \mathrm{~g} \mathrm{KCl}, 0.5 \mathrm{~g} \mathrm{MgSO} 4.7 \mathrm{H} 2 \mathrm{O} ; 0.01 \mathrm{~g}$ FeSO4.7H2O.

Cultivation: The cultivation medium containing chitosan as carbon source shows a composition for $1000 \mathrm{~mL}$ is given by: $2.0 \mathrm{~g}$ chitosan, $1.0 \mathrm{~g} \mathrm{NaCl}, 0.5 \mathrm{~g}$ (NH4)2SO4, $1.0 \mathrm{~g} \mathrm{MgSO}$, 0.5 g K2HPO4, 0.01 g ZnSO4.7H2O, 0.001 g FeSO4, 0.01 g CaCl2.2H2O, 0.0086 g MnSO4.7H2O. 
Inoculum preparation: To prepare the inoculum it was used 8 plates grown in CZA medium at $30{ }^{\circ} \mathrm{C}$ for 5 days. The biomass was transferred to an Erlenmeyer flask of $1000 \mathrm{~mL}$ containing $500 \mathrm{~mL}$ of fermentation medium CZA. It is noteworthy that in the medium preparation for inoculation were used two sources of carbon, chitosan and sucrose (CZA) in order to verify which allowed a greater cell growth.

\subsection{DeterminationofCellConcentration(Dry Mass).}

The cell concentration was obtained as follows: an empty Eppendorf was weighed (after being 24 hours in an oven), then added to $2.0 \mathrm{ml}$ of culture medium followed by centrifugation for 15 minutes. Then we removed the supernatant and placed on the Eppendorf with the solid residue resulting from the centrifugation in the oven for 24 hours then weighing yourself. The cell concentration $(\mathrm{g} / \mathrm{L})$ was obtained by equation 1 .

Cell concentration $(\mathrm{g} / \mathrm{L})=($ Weight of the Eppendorf with the centrifuge residue after 24 hours in a oven - Weight of empty Eppendorf)*500

\subsection{DeterminationofTotal Protein.}

The determination of total protein was performed in accordance with the modified method of Sedmak and Grossberg (1977) based on the decrease of absorbance of Coomassie blue dye, because of protein-dye binding, at $595 \mathrm{~nm}$ compared to maximum absorption at 465 $\mathrm{nm}$ according to Santos (2001).

\subsection{Determinationof Chitosanolytic Activity}

One unit of chitosanolytic activity (U.mL-1) was defined as the amount of enzyme required to produce 1 mol.min-1 of glucosamine per $\mathrm{mL}$ of enzyme extract. The chitosanolytic activity was achieved by monitoring the increase in total reducing sugars using the DNS (3,5-Dinitrosalicylic Acid) method from a standard curve for glucosamine.

\subsection{KineticAssay}

A kinetic assay was performed using Erlenmyer flasks of $250 \mathrm{~mL}$ containing $100 \mathrm{~mL}$ of culture medium with the following components in $1000 \mathrm{~mL}: 1.0 \mathrm{~g} \mathrm{NaCl}, 2.0 \mathrm{~g}$ chitosan, $0.5 \mathrm{~g}$ (NH4)2SO4, $1.0 \mathrm{~g} \mathrm{MgSO} 4,0.5 \mathrm{~g}$ K2HPO4, $0.01 \mathrm{~g} \mathrm{ZnSO} 4.7 \mathrm{H} 2 \mathrm{O}, 0.001 \mathrm{~g} \mathrm{FeSO} 4,0.01 \mathrm{~g}$ $\mathrm{CaCl} 2.2 \mathrm{H} 2 \mathrm{O}, 0.0086 \mathrm{MnSO} 4.7 \mathrm{H} 2 \mathrm{O}$, which were inoculated with $10 \%$ (vol/vol) of inoculum containing the fungus Aspergillusochraceus $(105 / \mathrm{mL})$ and cultured in a rotating incubator for 
108 hours at $150 \mathrm{rpm}$ (CHEN, 2005) and 30 ㅇ. A Aliquots were taken every six hours and analyzed for cell concentration, total protein and enzyme activity in supernatant.

\section{3 - RESULTS AND DISCUSSIONS}

\subsection{Selectionofstrainsproducingchitosan}

Initially in the Laboratory of Biochemical Engineering (LEB) there were some strains, previously isolated from soil, which were tested for their ability to grow on plates containing chitosan as the sole source of carbon and energy (CDA medium). Among the five strains tested only two were able to grow in CDA medium, as shown in Table 1. Initially the strains were identified by code and after selection it was chosen the strain that showed a better growth (3845) and this was sent to André Tosello Foundation (Campinas, São Paulo, Brazil) and identified as Aspergillusochraceus. It is noteworthy that, at least in the literature, was not found record of Aspergillusochraceus as chitosanase producer, although it is known that other species of Aspergillus are chitosanase producers, such as Aspergillus $\mathrm{sp}$. $\mathrm{Y} 2 \mathrm{~K}$, according to Cheng and Li (2000). Figure 1 shows a photograph of Aspergillusochraceus maintained in CZA medium.

Table 1.Selection of producing strains able to grow in CDA medium.

\begin{tabular}{cc}
\hline Strain & $\begin{array}{r}\text { Growing in CDA } \\
\text { medium }\end{array}$ \\
\hline $\mathbf{f 3 0 5 3}$ & No \\
3845 & Yes \\
4040 & No \\
4096 & No \\
4835 & Yes \\
\hline
\end{tabular}




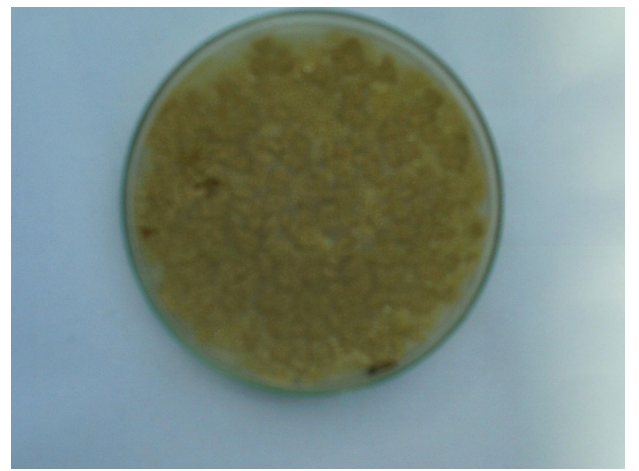

Figure 1 - Photograph of Aspergillusochraceus maintained in CZA medium.

\subsection{KineticStudy}

In order to determine the best conditions for production of fungal chitosanase was carried out a kinetic study in which the following parameters were monitored during 108 hours: cell concentration (gL-1), concentration of total protein (mg.mL-1) and chitosanolytic activity (U.mL-1). It is noteworthy that the inoculum for this study was already adapted to the medium containing chitosan as carbon source (ABDEL-AZIZ 1999). Figure 2 illustratesthe kinetic profiles obtained in this study.

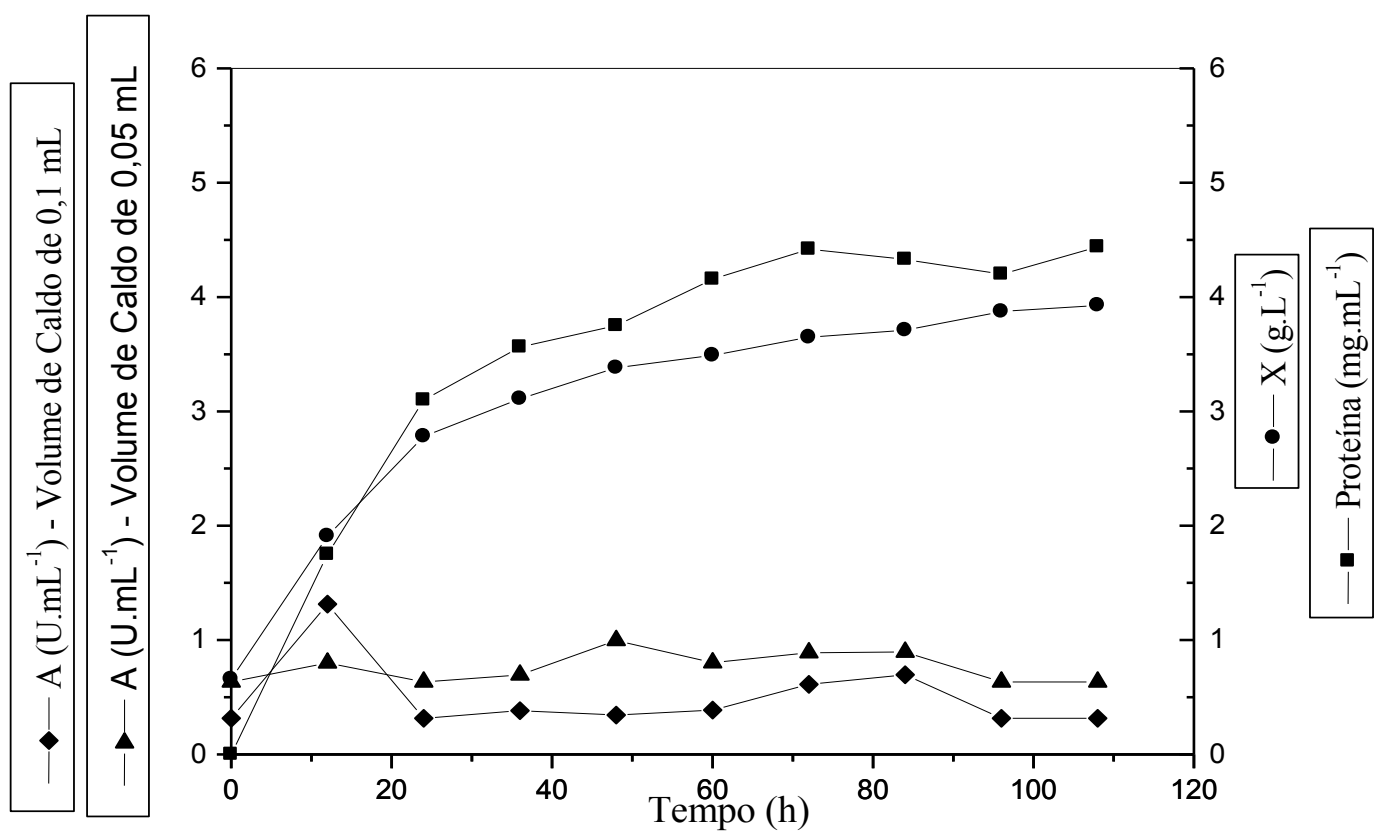

Figure 2 - Kinetic profiles for the production of chitosanase by Aspergillusochraceus in culture medium containing $0.2 \%$ chitosan. 
Observe that according to Figure 2 the cell concentration does not display the lag phase, since the cells were already adapted, or already using chitosan as a carbon source for the inoculum. The exponential growth occurs until approximately 36 hours during the beginning of cultivation, following the stationary phase which can be a cell concentration of around 4.0 g.L-1.

Regarding protein, there was a considerable increase of the same during the initial 24 hours of cultivation, and then a decrease in protein production when the culture is in the stationary phase.

Chitosanolytic activity was analyzed considering two different volumes of enzyme broth: $0.05 \mathrm{~mL}$ and $0.1 \mathrm{~mL}$. The results of activity analysis showed that for these different volumes, the chitosanolytic activity was $0.8 \mathrm{U} . \mathrm{mL}-1$ when using a volume of $0.05 \mathrm{~mL}$ of broth and was always greater than the chitosanolytic activity obtained for a volume of $0.1 \mathrm{~mL}$ of broth, except during the initial stage of cultivation when there was a significant increase in activity when was used a volume of $0.1 \mathrm{~mL}$. In this case, this result seems to indicate that there was possibly a mistake during the test with the volume of $0.1 \mathrm{~mL}$ at the time of 12 hours. Possibly an experimental error, since all other points showed consistency.

When analyzing the results together it is observed that increasing the cellular concentration and total protein during the early cultivation, the first 12 hours, coinciding with increased chitosanolytic activity, indicating that the Aspergillusochraceus has genes capable of inducing the production of chitosanase, and this synthesis is associated with growth, since both the activity and the curve of protein follow the curve of cell growth. Thus, since chitosan is used as the sole carbon source, the fungus excretes to the medium the chitosanase enzyme that hydrolyzes chitosan in chitooligosaccharides of lower molecular weight that are consumed by the microorganism. Whereas there is the induction of chitosanase during cultivation, although it was not monitored the consumption of substrate, it is observed that the enzyme production is associated with growth. This behavior is somewhat expected for the induction system with carbohydrates such as chitosan.

When assessing the difference in activity obtained by adopting different volumes of stock, it is observed that the $100 \%$ increase in volume of broth, i.e., from $0.05 \mathrm{~mL}$ to $0.1 \mathrm{~mL}$, there is a significant decrease in activity. However, since the substrate concentration in the assay is the same $(0.2 \%)$ and that there is a reduction in the volume of substrate solution that passes from $0.95 \mathrm{~mL}$ to $0.90 \mathrm{~mL}$, which implies a reduction of only $5.3 \%$ by mass, i.e., from 1.9 $\mathrm{mg}$ to $1.8 \mathrm{mg}$ of chitosan in the reaction medium it seems that such a reduction is justified only by the presence of some inhibitor.

It was conducted a second test of kinetic in order to observe the production of chitosanase with inocula obtained after five days from a specific medium for the growth of 
Aspergillusochraceus (CZA medium) and cellular concentration of 107 cells cultured for five days, which values are shown in Figure 3.

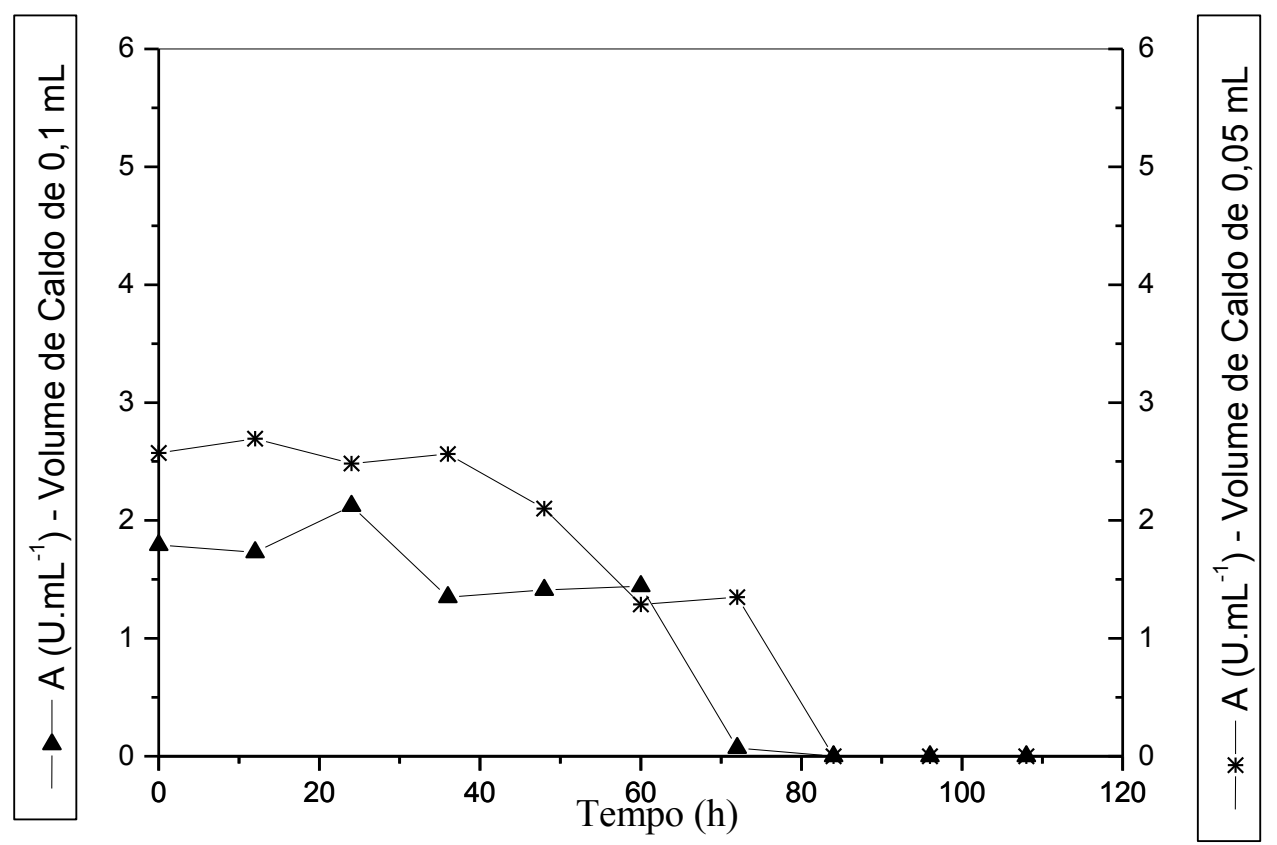

Figure 3 - Chitosanolytic activity produced by Aspergillusochraceus during submerged batch cultivation in culture medium containing $0.2 \%$ chitosan.

It is observed that the activities were always higher when used in the volume of 0.050 $\mathrm{mL}$ in broth assays. In this case, there was activity of approximately $2.7 \mathrm{U} . \mathrm{mL}-1$ during the first twelve hours of growth and the reduction of activity for a longer time of cultivation. It is noteworthy that there is already an initial activity at time zero, i.e. the time of inoculation due to the presence of reducing sugars formed during the inoculum. However, there is an increase in activity during the initial phase of cultivation.

\section{CONCLUSIONS}

After the development of this work, we observed that it was possible to isolate, among the microorganisms in Biochemical Engineering Laboratory, a strain capable of synthesizing chitosanase in the medium with chitosan as carbon source and identified as Aspergillusochraceus. It was also noticed that when using the volume of $0.050 \mathrm{~mL}$ of enzyme stock values of enzymatic activity was always higher when compared with the volume of 0.1 $\mathrm{mL}$ of enzyme broth. It was observed activity values of about $2.7 \mathrm{U} . \mathrm{mL}-1$ during the first twelve hours of culture as well as reduced activity for a longer time of cultivation. In relation 
to cell concentration it was verified that it did not show the lag phase, since the cells were already adapted to the culture medium, since both as means of maintaining the inoculum was composed of chitosan as a carbon source. Regarding protein, there was a considerable increase of the same during the first 24 initial hours of cultivation and then a reduction in protein production when the cultivation is in the stationary phase.

When analyzing the results together they showed that the increase in cell concentration and total protein at the beginning of cultivation, the first 12 hours, coincided with increased chitosanolytic activity, indicating that the fungus Aspergillusochraceus has genes that are capable of inducing production of chitosanase and this synthesis is associated with growth, since both the activity and the curve of protein follow the curve of cell growth.

\section{REFERENCES}

1. ABCC, Associação Brasileira de Criadores de Camarão. Censo das fazendas de camarão. 2004. Disponívelem <http://www.abccam.com.br>. Acesso em novembro de 2004.

2. CHENG, C. Y.; LI, Y., An Aspergilluschitosanase with potential for large-scale preparation of chitosan oligosaccharides. Biotechnol. Appl. Biochem., 32, 197-203, 2000.

3. POLIMAR (2003), Ciência é a nossa Natureza. http://www.polymar.com.br/quitosana/quito_his.htm

4. SANTOS, E. S. Recuperação e Purificação de Enzimas usando Adsorção em Leito Expandido, Tese de Doutorado, Universidade Estadual de Campinas, Campinas/SP, 152 p., 2001.

5. SEDMAK, J. J.; GROSSBERG, S. E., A rapid, sensitive and versatile assay for protein using coomassie brilliant blue G250, Analytical Biochemistry, v.79, p. 544-552, 1977.

6. Abdel-Aziz, S. M. (1999) jour. Of Basic Microbiol, 39, n. 2, 79-87.

7. Chen, X., Xia, W., Yu, X. (2005). Food Resear. Internat. 32, n. 3, 315-322.

8. Silva Filho, R. C.. (2005). Master Dissertation, Federal Universityof Rio Grande do Norte, $103 \mathrm{p}$.

9. Gooday, G. W. (1990) Biodegradation 1, 177-190. 